\title{
Impact of Water Hyacinth, Eichhornia crassipes (Martius) (Pontederiaceae) in Lake Tana Ethiopia: A Review
}

Melese Worku*, Samuel Sahile ${ }^{2}$

${ }^{1}$ Faculty of Agriculture and Environmental Sciences, Department of Forestry, Debre Tabor University, Debre Tabor, Ethiopia

${ }^{2}$ Associate Professor of Applied Microbiology and Plant pathology Postgraduate Directorate Director, University of Gondar, Ethiopia

\begin{abstract}
One of the lakes in Ethiopia knows as Lake Tana. It is located in Amhara regions the capital city of Bahar Dar town. In this lake in the resent year the very series problem in the areas know as Water hyacinth. Water hyacinth the distribution and abundance increase the current time and also strongly decreased water quality and intensity of aquatic biodiversity in the Lake. The objective of the review was the impact of water hyacinth, Eichhornia crassipes (Martius) Pontederiaceae) in Lake Tana Ethiopia. Water hyacinth in the lack and nearby the areas the local community its impact on series environmental problem and its influenced aquatics biodiversity. At present Water hyacinth (Eichhornia crassipses) have been first position as one of the worldwide most terrible invasive weeds source harms to millions of consumer of water resources.
\end{abstract}

Keywords: Lake Tana; Water hyacinth

\section{Introduction}

Lake Tana is one of important Lake in Amhara Rigion situated in Bahar Dar. This Lake is currently in a different problem like water hyacinth. Water hyacinth, Eichhornia crassipes (Martius) (Pontederiaceae), is a one of the free moving marine herb. Water hyacinth is the globe most terrible marine weed. Its dense increase hunk waterway and inhibit ship travel, disorderly trade, fishing and recreational activities. The plant is a weed of wetland crops such as rice and jute, and often clogs irrigation canals and pumps. Water hyacinth the first was recognized by the International Union for Conservation of Nature (IUCN) as one of the 100 maximum harsh destructive species [1-16] and documented as one of the top 10 worst weeds in the world [17]. It is measured by fast expansion rates, widespread spreading competences, huge and quick multiplicative output and wide-ranging environmental acceptance [18-22]. Water hyacinth one of difficulty knows as at this times flower all over the time and releases at least 3000 seeds per year, this is the dispersal rates very quick compared to other aquatic weeds [6]. And also each seeds are longterm, up to 20 years [7]. Even though the seeds of Water hyacinth might not be viable at all sites, then again water hyacinth frequently settles new spaces through vegetative reproduction and propagation of horizontally growing solons.

\section{The biology of water hyacinth}

The family Pontederiaceae has nine genera including Eichhornia, which has eight species of freshwater aquatics including water hyacinth (Eichhornia crassipes). Only E. crassipes is regarded as a pan-tropical aquatic weed [16] Water hyacinth is a permanent, marine plant, freefloating or anchor in low water. Generally $100-200 \mathrm{~mm}$ lofty, it can expand to 1 meter while increasing in thick mats. Roots of balanced plants are long and feathery. Vegetation of water hyacinth is sparkly dim green in colour, in rosettes with characteristic upright engorged bladder-like petioles. The name water hyacinth refers to its aquatic habitat and the resemblance of the flower colour to that of the garden hyacinth. Water hyacinth, a free-floating macrophyte, live at the airwater border and form two separate canopies: leaf canopies comprise above-water structures and root canopies comprising under water structure [3]. The mature WH consists of roots, rhizomes, stolons, leaves, inflorescences and fruit cluster (Figure 1).

\section{Invasion of the water hyacinth}

Invasion of the water hyacinth one of the difficulty unenthusiastic

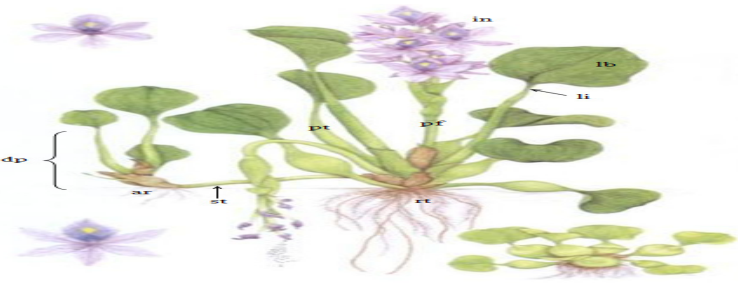

Figure 1: Morphology of water hyacinth plants with stolons.

ecological impact of the in Lake Tana such as disarticulation of biodiversity through deprivation of water quality and smothering of habitat by wide-ranging, permanent water hyacinth swathe The water under the internal of widespread stationary mats of water hyacinth was nearly devoid of oxygen, predominantly late in the nighttime and early in the sunup. Water hyacinth has invaded fresh water systems in over 50 countries on five continents. It is especially pervasive throughout Southeast Asia, the Southern United States, Central, East and Western Africa and Central America [15-22] Invasive water hyacinths are of a large apprehension in Ethiopia, affectation exacting problems lakes, rivers, power dams, water ways, roadsides and urban green spaces with great economic and ecological consequences. It is prevalent in tropical and subtropical water bodies where nutrient levels are often high due to agricultural runoff, deforestation and insufficient waste water treatment. In recent years, water hyacinth has spread faster, and the most serious infestation is in Ethiopia particularly in Lake Tana. One of the top ten ecologically dangerous and worst invasive weed, water hyacinth (Eichhornia crassipes) is aggressively infesting Lake Tana [1].

*Corresponding author: Melese Worku Abera, Faculty of Agriculture and Environmental Sciences, Department of Environmental Studies, Debre Tabor University, Debre Tabor, P.O. Box 272, Ethiopia, Tel: 251913986518; E-mail: melese1980@gmail.com

Received September 27, 2017; Accepted January 09, 2018; Published January 14, 2018

Citation: Worku Melese, Sahile Samuel (2018) Impact of Water Hyacinth, Eichhornia crassipes (Martius) (Pontederiaceae) in Lake Tana Ethiopia: A Review. J Aquac Res Development 9: 520. DOI: 10.4172/2155-9546.1000520

Copyright: $\odot 2018$ Melese W, et al. This is an open-access article distributed under the terms of the Creative Commons Attribution License, which permits unrestricted use, distribution, and reproduction in any medium, provided the original author and source are credited. 


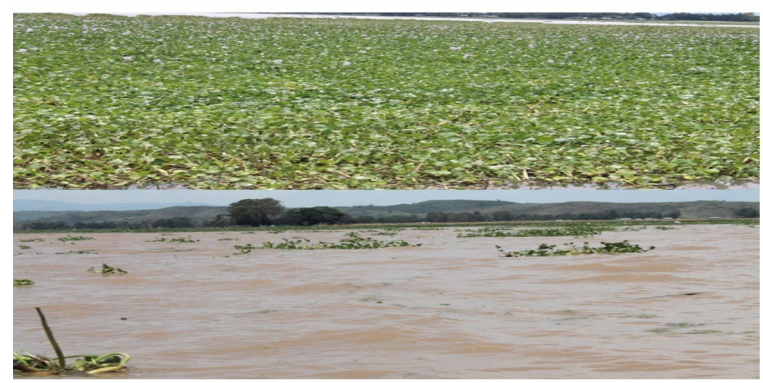

Figure 2: Dense mat and new invasion of hyacinth on Dembya and Gumara.

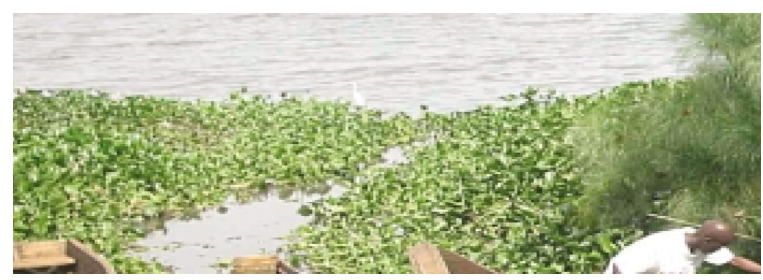

Figure 3: Physical control of water hyacinth Lake Tana.

The precise cause of water hyacinth invasion of Lake Tana is not well recognized. The first infestations were found near the mouth of the Megech River on the northern shores of the lake. A detailed survey estimating the water hyacinth coverage of the lake was 40,000 ha (Figures 2 and 3) of which Libo Kemkem Woreda shared 7,160.311 ha.

\section{The effect of Water hyacinth in Lake Tana aquatic biodiversity}

Water hyacinth persistent species are extensively conventional as one of the foremost cause of biodiversity loss and can have momentous possessions on resource accessibility and can restrain or improve the comparative great quantity of inhabitant species, without unavoidably being the powerful force behind community change [19]. The recent times in regional city Bahar Dar, in Lake Tana one of the recorded in world aquatic Biosphere Reserve in Ethiopia, so that this lakes Water hyacinth Eichhornia crassipes (Pontederiaceae, Liliales) one of the floating aquatic weed and the biosphere greatest destructive weed because of its harmful possessions on marine living organism in the lakes living the water body like fisheries, frogs, other and people's livelihoods from the surrounding lakes great influences on financial especially hindering problems on water transport activity, societal, healthiness related to reduced water quality of the lake and ecological. In the surrounding areas great problem on different types of diseased exposed the likes of malaria and bilharzia and snakes, water dirty creation the supply unsuitable for drinking and other domestic use. Natural foreign invasion be individual of the forceful forces of biodiversity defeat approximately the world [18-20]. Water hyacinth has caused severe environmental defeat of freshwater water bodies $[5,6]$. The weed out-competes the indigenous species due to its rapid reproductive ability, which poses a threat to aquatic biodiversity [6]. Due to its colonization, the water hyacinth also prevents the growth of vital phytoplankton, and ultimately affects fisheries and other vital aquatic animals [21] Lake of Tana generates various employment opportunities for local residents. This lake is a good job opportunity for the fishing industry, in the town of Bahar Dar. This product selling to hotels, restaurants, lodges etc. Water hyacinth was pronounced to encouragement destructively on the fitness of waterside communities. Decrease of oxygen levels in the water creates and atmosphere inappropriate for fish existence, consequently dropping species variety
[4] Water hyacinth was perceived to affect fisheries through reduced levels of production, a reduction in species diversity, poor quality fish, rising cost of operation resulting in lower income to fishers and higher prices to consumers [13]. In the Lake Tana at list Biosphere Reserve in Ethiopia, so that different type of the habitat of aquatic species. This one of the indicator Water hyacinth show that the fish loss of habitat, contamination of the water, fishing pressure subsidized to their deterioration [9]. Water hyacinth the series consequence of these inflows includes the death of fish from oxygen poisoning and amplified carbon dioxide and low oxygen meditation at evening and lastly diminution of the oxygen due to breakdown of the departed biomass of algae and phytoplankton [7] With substantial invasion it reasons very serious disturbance to commercial fishing, boat transport, and infrastructure such as water supply by obstructive the consumption points, port facilities and the hydro-electricity generation. Under heavy infestation the socio-economic structure, food supply and health of the societies exist in around the lake are extremely worried [7]. The enlarged water hyacinth invasion has, therefore, obstructed damagingly on the water quality and amount, fishing activities, plankton life, farming and health. Rapid growth rate and infestation on large water area is causing different problems [17-22]. The weed affects solar light penetration into water bodies, reduces oxygen through decomposition, alters chemistry of water and substantially increases water evapo transpiration [10]. Eichhornia crassipes (Mart.) is a freefloating perennial hydrophyte belonging to the family Pontederiaceae. The leaves are broad, thick, glossy, and ovate and float above the water surface. They have long, spongy and bulbous stalks. The feathery, freely hanging roots are purple-black. It is one of the most productive plants on the earth and is considered the world's worst aquatic weed. It tolerates annual temperatures ranging from $21.1^{\circ} \mathrm{C}$ to $27.2^{\circ} \mathrm{C}$ and its $\mathrm{pH}$ tolerance is estimated at 5.0 to 7.5. The 'beautiful blue devil' water hyacinth, grows rapidly as a dense green mat over stagnant water bodies such as lakes, streams, ponds, waterways, ditches and backwaters and is recognized by its lavender flowers and shinning bright leaves. The plant is euryhaline, tolerating both fresh and marine water; hence it spreads at an alarming rate [14]. The so called "menace and nuisance" has tremendous potentiality of high rates of vegetative growth. The plant is now considered as a serious threat to biodiversity. The environmental hazards associated with these plants are degraded water quality and drastic changes in the plant and animal community, light and oxygen diffusion are severely curtailed reduction in water movement etc.

\section{Water hyacinth control and management}

Water hyacinth is enormously difficult to eliminate once established. The goal of most management efforts is to minimize economic costs and ecological change. Recent literature on management of water hyacinth focuses on techniques to remove the weed, however, little has been done to assess the full extent of ecological changes that may occur in response to the establishment of this weed. Efforts have been made by various countries to control or manage the water hyacinth. These method choices from mechanical and material elimination of the hyacinth, biological control to substance utilize, but no method has completely succeeded in controlling the menace. There are three main method of manager of this infamous weed that is physical, chemical and genetic. Physical control involves both manual and mechanical removal, a boring and prolonged use, connecting the use of enormous and extremely exclusive equipment and human being labor.

\section{Discussion}

\section{Control measures for water hyacinth}

Present are three key controls way for association of water hyacinth. 
Citation: Worku Melese, Sahile Samuel (2018) Impact of Water Hyacinth, Eichhornia crassipes (Martius) (Pontederiaceae) in Lake Tana Ethiopia: A Review. J Aquac Res Development 9: 520. DOI: 10.4172/2155-9546.1000520

Page 3 of 3

Biological control: This is a long-term direct practice and is suggested for its consumer friendly and provides a sound financial and sustainable manage way [10]. These techniques involve the host precise established challenger to decrease the inhabitant's attentiveness of the weed. Numerous insects like weevils, moth and fungi are use as control agents for the water hyacinth [2]. In Australia, the technique has been successful through ordinary discharge of the weevils Neochetina eichhorniae and N. bruchi, and the moth Sameodes albiguttalis, and has effectively reduced the inhabitants' density of water hyacinth [11]. Also in Lake Victoria organic control under surveillance and regular monitor has been productively practical to defeat water hyacinth [12].

Physical control: Although this method is regularly worn roughly the humankind, it is very select to be appropriate and use equipment such as automatic mowers and dredgers. The method can only resolve little infected areas hence are not a sustainable long term solution [10]. It requires fleet of motor vehicle to move immense quantities of water hyacinth after it has being impassive and the mats of water hyacinth can have a density of up to 200 tons per acre [8].

Chemical control: This method uses herbicides such as 2, 4-D, Diquat and Glysophate to manage water hyacinth [11]. It is most excellent for little invasion area not big areas. Appliance is ready each on the earth or air with accomplished operator. The technique has ecological and healthiness alarm as herbicides can be injurious, predominantly source used for expenditure and wash [10]. Apart from the three control methods, Harley et al. [8] recommended to if the amount of nutrients incoming any water body is decrease, this repetitively reduce the invasion and expansion of the water hyacinth.

Integrated control approach: To sustainably supervise and manage the extent of the unfamiliar species; an integrated manage advance is necessary, where substance, mechanical and normal controls are used jointly. Different manage method addition each other and where likely have a preservative effect.

\section{Conclusion}

The end invention of the water hyacinth attack has always had a harmful shock on the financial, environmentally and ecological point of view. In Lake Tana the current status of lack at this time under question marks. The fishers and community approximately Lake Tana depends principally on the Lake as a source of their income. Their expectant of supporting themselves cost-effectively should be made probable through participatory control management approach to ensure the health of the lake's ecosystem. The aquatic living organism seriously affect caused by oxygen depletion in the lake.

The consequences of water hyacinth reducing aquatic biomass in Lake Tana are finally the responsible body shall encourage distributing the messages for local community. The advertising witin social Medias with full stands by using Ethiopia television program, large billboard, mass media, radio and prepared official calendar. Help for sustainable aquatic biodiversity conservation in the Lake Tana to protecting environmental and can be beneficial to the natural environment by providing for conservation aquatics resources.

\section{References}

1. Ayalew W, Ali S, Eyayu M, Goraw G, Gebriel W (2014) Water Hyacith Coverage Survey Report On Lake Tana. Technical Report Series 1.
2. Cilliers CJ, Campbell PL, Naude D, Neser S (2003) An integrated water hyacinth control programme on the vaal river, in a cool, high altitude area in south Africa. Plant Protection Research Institute, Agricultural Research Council, Pretoria South Africa.

3. Downing-Kunz MA, Stacey MT (2012) Observations of mean and turbulent flow structure in a free-floating macrophyte root canopy. Limnol Ocean Fluids Environ 2: 67.

4. Gerry H, Waage J, Phiri G (1997) The problem in tropical Africa. Report Prepared for the First Meeting on andInternational Water Hyacinth Consortium Held at the World Bank, Washington D.C., USA.

5. Gichuki J, Odhiambo W (1994) The role of macrophytes in the economy of lower Sondu-Miriu river of lake victoria. The African J Tropical Hydrobiol Fish 5: 69-78.

6. Gichuki J, Omondi R, Boera P, Okorut T, Matano AS, et al. (2012) Water hyacinth eichhornia crassipes; laubach dynamics and succession in the nyanza. Sci World J pp: 106-429.

7. Gopal B (1987) Aquatic plant studies, Water Hyacinth.

8. Harley LS, Julien MH, Wright AD (1997) Water hyacinth: A tropical world-wide problem and methods for its control, proceedings of the first meeting of the International Water Hyacinth Consortium, World Bank pp: 18-19.

9. Hecky RE (1993) The eutrophication of Lake Victoria. Verhandlungen der Internationale Vereinigung für Theoretische Angewandte Limnologie 25: 39-48.

10. Intermediate Technology Development Group (ITDG) (1997) Water hyacinth control and possible uses. knowledge and information service. The Schumacher Center for Technology and Development, Bourton Hall, UK.

11. Labrada R, Charudattan R, Center TD (1996) Strategies for water hyacinth control: Report of a Panel of Experts Meeting, Food and Agriculture Organization of the United Nations, Rome, Italy.

12. Lake Victoria Basin Commission (2016) Lake Victoria Environmental Management Programme II.

13. LVEMP (1995) Lake Victoria environmental Management Programme. Report Submitted by Kenya, Uganda and Tanzania to World Bank p: 321.

14. Lata N, Veenapani D (2011) Response of water hyacinth manure on Growth attributes and yields in Brassica Juncea.

15. Lu J, Wu J, Fu Z, Zhu L (2007) Water hyacinth in China: A sustainability science based management framework. Environ Manage 40: 823-830.

16. OEPP/EPPO (2008) Data sheets on quarantine pests Eichhornia crassipes. Bulletin OEPP/EPPO Bulletin 38: 441-449.

17. Shanab S, Shalaby E, Lightfoot D, El-Shemy H (2010) Allelopathic effects of water hyacinth (Eichhornia crassipes) 5: 13200

18. Pyšek P, Richardson D (2010) Invasive species, environmental change and management, and health. Annual Review of Environment and Resources 35 25-55.

19. Wilson JR, Holst N, Rees M (2005) Determinants and pattern of population growth in water hyacinth. Aquatic Botany 81: 51-67.

20. Vila M, Espinar J, Hejda M, Hulme P (2011) Ecological impacts of invasive alien plants: a meta- analysis of their effects on species, communities and ecosystems. Ecol Lett 14: 702-708.

21. Villamagna A, Murphy B (2010) Ecological and socio-economic impacts of invasive water hyacinth (Eichhornia crassipes): A review. Freshwater Biol 55: 282-298.

22. Zhang Y, Zhang D, Barrett S (2010) Genetic uniformity characterizes the invasive spread of water hyacinth (Eichhornia crassipes), a clonal aquatic plant. Mol Ecol 19: 1774-1786. 